\title{
A hospice önkéntesség lélektani vonatkozásainak szakirodalmi áttekintése
}

\author{
DORNER LÁSZLÓ* - FÜRNÉ MOSONI ANITA - HATVANI ANDREA
}

\author{
Eszterházy Károly Egyetem Pszichológia Intézet, Eger
}

(Beérkezett: 2016. július 1., elfogadva: 2017. január 19.)

Háttér és célkitüzések: Jelen tanulmány célja, hogy áttekintse és rendszerezze a hospice önkéntesség lélektani vonatkozásait vizsgáló kutatások elmúlt évtizedekben született eredményeit, különös tekintettel az önkéntes tevékenységeinek, személyiség- és motivációs hátterének kutatásaira. Módszer: Tudományos adatbázisokban történő kulcsszavas keresés és a téma szempontjából releváns magyar (Kharón Thanatológiai Szemle) és angol nyelvú közlemények $(n=60)$ kiválasztása után azok szisztematikus szakirodalmi áttekintése különböző témák alapján (motivációk, személyiség, észlelt kihívások, stressztényezők). Eredmények: A kutatások nagy része kiemeli, hogy míg a hospice szolgáltatások elkezdése, majd később folytatása is jelentős összefüggést mutat a magas szintú altruisztikus motivációkkal (pl. társadalmi felelősségvállalás, mások fájdalmának enyhítésére irányuló vágy, proszociális értékek kifejezése, morális felelősség), addig az egoisztikus motivációk (pl. önértékelés növelése, személyes növekedés, szociális kapcsolatok, karrier) főként az önkéntesség kezdeti szakaszában fontosak, és a hosszú távú önkéntessé válás során már kevésbé meghatározónak tekinthetők. Bár a személyes érintettség (pl. egy hozzátartozó halála vagy saját betegség) gyakori motívum az önkéntesség elkezdésének hátterében, a hosszú távú önkéntessé válásra az önkéntesként megélt tapasztalatok (a valahová tartozás érzése, jelentőségteljes munka végzése és a hospice team tagjaival való hatékony együttmúködés) gyakorolják a legjelentősebb hatást. Az önkéntesek személyiségvonásait vizsgálva az életkori vagy nemi sztenderdekhez, illetve az önkéntes tevékenységeket nem végzőkhöz képest általában magasabb Extraverzió, Barátságosság és Nyitottság, valamint alacsonyabb Neuroticizmus pontszámokat találunk. Természetesen az további vizsgálat tárgyát képezheti, hogy ez az eredmény az önkéntesség hatására jött létre, vagy eleve azok jelentkeztek önkéntesnek, akik ezekkel a pontszámokkal voltak jellemezhetóek. Ugyancsak összekapcsolódik a hospice önkéntességgel a magasabb empátiás törődés, gondoskodásigény és szociális nézőpontváltásra való képesség is, amelyek nélkül a nehéz érzelmi helyzetekkel (kliensek elvesztése, nővérektől és hozzátartozóktól érkező elutasítás) való hatékony megküzdés elképzelhetetlennek tûnik. Következtetések: A hospice önkéntesség egy magas frusztrációs toleranciát, folyamatos önismereti munkát és hatékony megküzdési módokat igénylő önkéntességtípus. Ennek lélektani szempontú vizsgálatakor egyaránt figyelembe kell vennünk az önkéntes személyre és az önkéntesség haszonélvezőjének pszichés jellemzőire gyakorolt hatást.

Kulcsszavak: hospice önkéntesség, motiváció, stressz, személyiség

\footnotetext{
* Levelező szerző: Dorner László, Eszterházy Károly Egyetem Pszichológia Intézet, 3300 Eger, Klapka u. 12. E-mail: dorner.laszlo@uni-eszterhazy.hu
} 


\section{Bevezetés}

Napjainkban a fejlett országokban élő emberek egyre hosszabb ideig élnek. Ez - részben az orvostudomány fejlődésének következtében - azzal is együtt jár, hogy ma hosszabb ideig élünk együtt krónikus betegségeinkkel is. Egyre több krónikus beteg idós ember van, így az egészségügyi ellátó rendszer szerepe is egyre fontosabbá válik. A magyar népesség egészségi állapota meglehetősen rossz. ${ }^{1}$ Az idő előtti elhalálozás mértékét mutató adatok alapján Magyarország világviszonylatban „dobogós helyen” áll. A halálokok között a szív- és érrendszeri betegségek állnak első helyen az összes halálozás mintegy felét okozva. A halálozás mintegy negyedéért a daganatos betegségek felelősek. A betegség miatt elvesztett életévek számát tekintve azonban ez az arány megfordul: a daganatos betegségek miatt elvesztett életévek száma mintegy kétszeresen meghaladja a szív-és érbetegségek miatt elveszett életéveket, mert a rák már fiatalabb életkorban is több áldozatot követel. ${ }^{2} \mathrm{E}$ betegségek népegészségügyi jelentósége tehát kiemelkedő.

A daganatos betegségek kezelése az orvostudomány fejlődésének, a kezelési technikák korszerúsödésének, és a génkutatás széleskörúvé válásának eredményeként egyre sikeresebb, a betegek nagy részének gyógyulási esélye megnőtt, mégis a nagy előfordulási arány következtében a terminális állapotú betegek száma is növekedett. ${ }^{3}$

Mindemellett „,a fejlett országokban a halál, és a haldoklás körülményei is megváltoztak. Az emberek 70-80\%-a kórházi körülmények között hal meg, a hozzátartozók akár objektív, akár szubjektív lelki okokból csak ritkán képesek megteremteni az otthoni haldoklás lehetőségét. »Nem tudnak mit kezdeni « a helyzettel, a haldokló szobájában lenni kínos, de nem ott lenni még kínosabb. A valóban megterhelő együttlét és búcsú helyett gyakran megelégszünk a mindent megtettünk megnyugtató tudatával, sokszor még a haldoklás eltitkolásának közös játszmáját is inkább felvállaljuk, minthogy hazugságok és magányra utalás nélkül fejezzük be kapcsolatunkat a távozóval" (Kárpáty, 2002, 15. o.).

Mindezek a tényezők mutatják a palliatív ellátás és a hospice mozgalom, valamint az ott dolgozó önkéntesek munkájának a fontosságát.

Az utóbbi évtizedekben az önkéntesség lélektani hátterével kapcsolatban számos olyan kutatás indult (lásd pl. Claxton-Oldfield \& Banzen, 2010;

1 Letöltve: 2016. 11. 06-án: https:// www.antsz.hu/data/cms41690/lakossagi_szurovizsgalatok.pdf

2 Letöltve: 2016. 11. 06-án: https:// www.antsz.hu/data/cms41690/lakossagi_szurovizsgalatok.pdf

3 Letöltve: 2016.11.08-án: http://www.hospice.hu/docu/Szakmai_iranyelvek.pdf 
Claxton-Oldfield, Claxton-Oldfield, \& Paulovic, 2013), amely a motivációs háttér (az önkéntesség elkezdése és a hosszú távú önkéntessé válással öszszefüggésben egyaránt), a személyiség-összetevők (pl. empátia, proszociális személyiség) szerepét és az önkéntes, valamint az önkéntesség haszonélvezője (pl. kórházi beteg) pszichés jellemzőire gyakorolt hatását igyekezett feltárni. Stroebe, Schut és Stroebe (2007) longitudinális vizsgálata szerint a partner elvesztése szignifikánsan növeli a másik fél mortalitási esélyét, valamint betegségekre való hajlamát. Számottevő protektív tényezőnek tekinthetó azonban a mások segitésére irányuló aktivitás: Brown, Brown és Preston (2011) kutatásában például azok a személyek, akik a szeretett személy elvesztését követő 6 hónapban más emberek érdekében végeztek önkéntes munkát, a következő évben számottevően alacsonyabb depresszió-szintet mutattak. Ez az összefüggés kifejezettebben jelent meg az erőteljesebb gyászreakciókat mutató személyeknél, mint az enyhe gyászreakciókat mutató személyeknél. A segítés ugyanis nagy valószínúséggel - függetlenül a mögöttes szándékoktól és kognícióktól - pozitív érzelmeket vált ki az azt végző személyekben, ami viszont egyértelmúen csökkenti a distressz szintjét, így javítva a pszichés és szomatikus egészségmutatókat (McEwen, 1998).

\section{Módszer}

A szakirodalmi összefoglaló tanulmányunk elkészítéséhez kizárólag tudományos adatbázisokban elérhető angol és magyar nyelvú közleményeket vizsgáltunk a 2016. június hónapban online elérhetó lektorált publikációk közül, szürke irodalom (disszertációk, konferencia kiadványok, szakmai beszámolók, kutatási jelentések) nem képezte részét a vizsgálatnak. Ezen kereten belül azonban törekedtünk a lehető legszélesebb szakirodalmi áttekintésre. Nyílt hozzáférésú (Google Tudós, ERIC), illetve a felsőoktatási intézmény által előfizetett adatbázisokban (EBSCO Discovery Service, SAGE, JSTOR, Science Direct, Springer Link, PubMed) kulcsszavak segítségével történt a szakirodalom keresése ("hospice”; "terminal care”; "hospice volunteer"; "hospice volunteer motivation"; "palliative care volunteer", "stress in hospice", „coping in hospice") kulcsszavak felhasználásával. Azon cikkeket, amiket a szerzők nem tudtak letölteni, az absztrakt alapján viszont szükségesnek látszottak, könyvtárak közötti együttmúködéssel sikerült megszerezni. A 60 kiválasztott tudományos cikket (áttekintő tanulmányok, kvalitatív és kvantitatív módszertannal történő keresztmetszeti és longitudinális vizsgálatok) néhány, a korábbi szakirodalmi hivatkozások által a hospice önkéntesség szempontjából relevánsnak mutatkozó szempont szerint csoportosítottuk: a hospice önkéntesség pszichés jellemzőkre gyakorolt hatását, a hospice önkéntesek személyiséghátterét és motivációit, továb- 
bá az önkéntesek hospice-ban megélt tapasztalatait bemutató cikkek. Azok a tanulmányok kerültek az adatbázisunkba, amelyek a cikkek átolvasása után kellően informatív, a vizsgált téma bemutatásához és megértéséhez nélkülözhetetlen, korszerú és releváns tudásanyagot tartalmaztak.

\section{A hospice-ról és a palliatív szolgáltatásokról}

Az Egészségügyi Világszervezet (WHO ${ }^{4}$ meghatározása szerint „A palliatív ellátás olyan megközelítés, amely az életet megrövidítő betegség kísérő problémáitól szenvedő páciens és családja életminőségét javítja azáltal, hogy megelőzi és csillapítja a szenvedést a fájdalom, a fizikai, pszichoszociális és spirituális problémák meghatározásával, kifogástalan értékelésével és kezelésével. A palliatív gondozás csillapítja a fájdalmat és az egyéb kínzó tüneteket; az életet és a halált normális folyamatnak tartja; nem tesz semmit a halál megrövidítése és meghosszabbítása érdekében; integrálja a betegellátásba a pszichológiai és spirituális tényezőket; támogató rendszert kínál, hogy a beteg a lehetó legaktívabban élhessen a halálig; támogató rendszert kínál a család számára a betegség ideje alatt és a gyász időszakában; teammunkát alkalmaz, amely a beteg és családja szükségleteire irányul, beleértve a gyász-tanácsadást, ha az javasolt; kiemeli az életminőséget, és ugyanakkor pozitívan viszonyul a betegség folyamatához; alkalmazható a betegség korai stádiumában, az életet meghosszabbító terápiákkal - mint a kemoterápia és radioterápia - együtt, és magában foglalja azokat a szükséges vizsgálatokat is, amelyek szükségesek a kínzó klinikai komplikációk jobb megértéséhez és kezeléséhez." ${ }^{5}$

A hospice egy olyan aktív, megfelelő szakmai háttérrel támogatott, humanisztikus elveken és sajátos filozófián alapuló szolgáltatás, amely olyan betegek számára igyekszik magas színvonalú segítséget adni, akiknek egészségi állapota folyamatosan romlik, és a gyógyulás esélye minimális. A hospice holisztikus szemléletú, nemcsak a beteg mint „egész ember” fontos számára, hanem a családot is maximálisan bevonja és az ő lélektani hátterükkel is igyekszik foglalkozni (pl. gyászfolyamatban segítséget ad). Ebben a folyamatban szociális, érzelmi és spirituális elemeket egyaránt megtalálhatunk. Olyan team áll a beteg rendelkezésére, amely különböző szakembereket foglal magába (orvos, nóvérek, szociális munkások, otthoni ápolók). Az előbbi felsorolást kiegészítendő, az önkéntesek is igen fontos

\footnotetext{
4 Letöltve: 2016. 11. 06-án: www.who.int/nmh/Global_Atlas_of_Palliative_Care.pdf

5 Letöltve: 2016. 10. 21-én: http://www.hospice.hu/hospice-alapfogalmak/
} 
láncszemét képezik a hospice szolgáltatásnak, hiszen a beteg számára gyakran csak ők képviselik a külvilágot, kielégítik az emberi kapcsolatok iránti igényüket, gondoskodásukkal csökkenthetik a szenvedést. ${ }^{6}$

A hospice és palliatív ellátás a terminális időszakra vonatkozik, amely néhány hónaptól akár csak napokra terjed és az agonális időszakkal fejeződik be. A betegek akkor kerülhetnek hospice gondozásba, amikor már kuratív kezelésben nem részesülhetnek. ${ }^{7}$

\section{Az önkéntesség helye a hospice-ban}

A hospice önkéntes számos olyan feladatot láthat el a szervezeten belül, amellyel a betegek körülményeit javítja, élete utolsó időszakának szenvedéseit csökkentheti. Farkas (2016) friss kutatása alapján 3 fő részre oszthatjuk ezen tevékenységeket:

1. Betegágy melletti munkák: Közvetlen segítés, például fózés, étkezés, felolvasás, sétákon való kísérés, betegfelügyelet, pszichoszociális támogatás, kapcsolattartás különböző szociális egységekkel (önkormányzatok, ételfutárok). Feladatuk még az otthoni ellátásban részesülő betegek meglátogatása és a gyászoló családok támogatása.

2. Ügyintézés: Átmenetet képez, nem a betegágy mellett történik, hanem a beteg ügyeit intézi és a szolgáltatókkal lép kapcsolatba. Ide tartozik a gyógyszerek felíratása, kiváltása, bevásárlás, a betegek személyes ügyeinek intézése, postai küldemények átvétele és feladása, levélírás, kerti munkálatok elvégzése.

3. Háttérmunkálatok: Ezen tevékenységek végzésekor nem a beteggel áll kapcsolatban az önkéntes, hanem a szolgálat munkáját segíti, például adminisztrációs munkával, szervezési feladatok végzésével, PR és marketing tevékenységgel, szervezeti kommunikációs feladatokkal, adománygyújtéssel.

A fenti, igen részletes listát Brown (2011a) összegzése alapján néhány egyéb lehetőséggel is kiegészíthetjük: az önkéntes beszélgethet a betegekkel hobbijaikról, közös játék, felolvasás, spirituális támogatás nyújthat örömet a betegnek, miközben az önkéntes jelenléte állandóságot és biztonságérzetet adhat. Mivel az önkéntes nem érintett érzelmileg annyira, mint a család, a beteg vele mindig őszintén beszélhet érzéseiról, fájdalmairól. Ha olyan speciális szakértelemmel rendelkezik, amelyre a betegek igényt tarthatnak (pedikúr, fodrász, kertész), aktívan gyakorolhatja azokat. Egyes országok-

6 Letöltve: 2016. 10. 21-én: http:// www.hospicehaz.hu/almenuk/a-hospice-ellatasrol

7 Letöltve: 2016. 10. 21-én: http://www.hospice.hu/hospice-alapfogalmak/ 
ban kiegészítő terápiát is nyújthat a betegeknek, valamint, ha rendelkezik az ehhez szükséges tapasztalattal és végzettséggel, akkor - az egyébként igen jó hatásfokkal alkalmazható - zene- és múvészetterápia eszköztárát is alkalmazhatja a betegek érdekében. Értesítheti az orvost arról, hogy valamely beteg segítségre szorul. Összegezve: alapos tréning után minden olyan tevékenységet végezhet, melyhez rendelkezik megfelelő kompetenciákkal, mely megfelel az intézményi szabályzatnak és egybeesik a beteg és családjának erre vonatkozó igényeivel (Brown, 2011a).

Egy korábbi vizsgálatban megfigyelték, hogy az önkéntesek életkora öszszefüggésben áll a hospice szolgáltatásban betöltött szereppel: szignifikánsan több fiatal önkéntes végez közvetlen betegellátási feladatokat, míg az idősebbek inkább az egyházi és adománygyưjtő feladatokkal foglalkoznak (Black \& Kovacs, 1999). Ennek hátterében fontos megállapítanunk, hogy míg Magyarországon a Hospice szolgáltatás jellemzően nem egyházi intézményekben kap helyet, addig Európa egyes országaiban (pl. NagyBritannia) erős az egyházi meghatározottság e téren. Az életkor szerepét vizsgálva azt is érdemes hozzátennünk, hogy azok a 65 évnél idősebb személyek, akik maguk is végeznek önkéntes munkát, alacsonyabb halálozási rátát, jobb egészségmutatókat és alacsonyabb depresszió szintet mutatnak (Musick \& Wilson, 2003), valamint az önértékelésük is magasabb (Wuthnow, 2001). Ennek oka kettős: vagy az eleve magasabb önértékelésú személyek vállalnak nagyobb valószínúséggel önkéntes munkát, vagy az önkéntesség önjutalmazó jellegéből és a munkavégzés eredményének folyamatos visszacsatolásából fakadóan növekszik az önértékelés. Megfigyelhetjük, hogy amennyiben az önkéntes koordinátor érdemben foglalkozik az önkéntesek szervezeten belül betöltött szerepével, jelentőségteljes és kihívást nyújtó, ugyanakkor teljesíthető feladatokkal látja el az önkéntest, világos szerephatárokat állít fel (pl. a hospice team fizetett tagjainak feladatai és az önkéntes szerepei között), akkor az önkéntes nemcsak költséget csökkent, hanem a szolgáltatás minőségét is javítja. Olyan személyközi interakciókban is segítheti a beteget, amire a fizetett szakembereknek nem marad elég ideje vagy energiája (Firth, 2013).

\section{A hospice önkéntesek motivációs háttere}

\subsection{Az önkéntesség motivációs hátteréről általában}

Az önkéntesség motivációs struktúráját vizsgálva a motívumok igen széles spektruma bontakozik ki a szakirodalom tanulmányozásakor (Finkelstein, 2009). Az 1990-es évek legnagyobb hatású elmélete az ún. funkcionális modell (Clary és Snyder, 1991; Clary és mtsai, 1998) szerint egy tevékenység végzé- 
se minden személy esetében más és más pszichés funkciókat szolgálhat, így az önkéntesség által az egyéni szükségletek függvényében számos motívum kielégülhet, amely egyben az önkéntes tevékenységek fenntartásának alapját is képezi. Ugyanaz az önkéntes munka eltérő szerepet tölthet be a különböző egyéneknél, és az egyes személyek önkéntességre irányuló motivációi is változhatnak idővel (Finkelstein, 2009). A modell alapján kidolgozott Önkéntes Funkciók Leltára (Volunteer Functions Inventory, VFI; Clary és mtsai, 1998) az önkéntesség végzése mögött hatféle motívumot (viselkedésre késztető belső tényezőt) jelenít meg:

1. Érték dimenzió: azért végez önkéntes tevékenységet, hogy fontos értékeket fejezzen ki vagy múködtessen, mint például az emberiesség vagy a kevésbé szerencsés helyzetben levők segítése;

2. Megértés szükséglete: az a szándéka, hogy többet tudjon meg az őt körülvevő világról és fejlessze a kevéssé használt képességeit;

3. Növekedés szükséglete: célja, hogy a személy pszichológiai értelemben fejlődjön az önkéntes tevékenység közben átélt pozitív érzések hatására, miközben önbecsülése növekedését és a személyes fejlődés érzését is megtapasztalhatja.

4. Karrierszükséglet: célja a pályájával összefüggő tapasztalat növelése és jobb karrierlehetőségek szerzése az önkéntesség által (pl. önéletrajz);

5. Társas szükséglet: az önkéntesség által a személy bővíteni igyekszik társas kapcsolatait, vagy számára fontos személyek elismerését szerezheti meg;

6. Énvédelem szükséglete: azért önkénteskedik, hogy csökkentse negatív érzéseit, mint a búntudat, vagy személyes problémáit megossza másokkal.

Az elmélet szerint az önkéntes addig folytatja proszociális tevékenységeit, míg az önkéntes tevékenysége közben szerzett tapasztalatai és élményei által a számára fontos motívumokat képes kielégíteni. Az önkéntesség kutatásában a funkcionális modell elmélet számos esetben alátámasztást nyert, azonban néhány esetben bírálták azt (Finkelstein, 2009).

\subsection{A hospice önkéntesség motivációs háttere}

Clary és Snyder (1999) 61 kórházi önkéntest vizsgált közvetlenül az önkéntessé válása idején a motivációs hátteréről, majd később az önkéntesként szerzett tapasztalatairól. Eredményeik alapján elmondhatjuk, hogy azok az önkéntesek, akik az előzetes elvárásaiknak és motivációs késztetéseiknek megfelelő tapasztalatokat élnek át önkéntes munkájuk során, sokkal elégedettebbek a munkával és jobban kötődnek a delegáló szervezetükhöz is, ami az önkéntesség időtartamát jelentősen megnövelheti, miközben a ki- 
égés valószínűsége is csökken. Guirguis-Younger és Grafanaki (2008) kiemelik az önkéntesek azon szükségletét, hogy szabadon megválaszthassák a rendelkezésükre álló szabadidő eltöltésének módját és teljes emberként, rugalmasan, erősségeiket felhasználva segíthessenek másokon. Ugyancsak kiemelik a reziliencia és a szívósság szerepét a hosszú távú önkéntessé válásban.

Egy másik jelentős kutatásban Scott és Caldwell (1996) az alábbi motívumokat azonosította a hospice önkéntesség hátterében: társas támogatást nyújtó önkéntes csoport tagjának lenni, folyamatos tréninglehetőségek, az önfejlesztés igénye, az önkéntes társak mélyebb megismerésének lehetősége, hit a hospice szellemiségében és hasznosságában, jó kapcsolat létesítése a fizetett munkatársakkal (pl. ápolók), értékesnek, hasznosnak érezni magát, önkiteljesítés és önmegvalósítás.

Stelzer és Lang (2016) USA-beli és németországi hospice és nem hospice szolgáltatásokban dolgozó 125 önkéntes (22-93 évesek) motivációs hátterét vizsgálva számos hasonlóságot és néhány különbséget azonosított. A hospice önkéntesek elsődleges motivációja a tevékenység elkezdésére a másokon segítés vágya, új tapasztalatok és társas kapcsolatok keresése, és a személyes növekedés szükséglete volt. Az amerikai önkéntesek altruisztikus motivációkat, a személyes növekedést és a társas kapcsolatokat, míg német társaik a karrierrel kapcsolatos motivációikat jelölték meg a legfontosabbnak. Utóbbi nemzet önkénteseinél csoportonként is jól megfigyelhető különbségeket mutattak ki: a hospice szolgáltatásban dolgozók inkább a másokon való segítést, míg a nem hospice-ban dolgozó kórházi önkéntesek az énjük fejlődését tekintették elsődleges motívumnak (Stelzer \& Lang, 2016). Természetesen az önkéntesség elkezdéséhez olyan alapvető életszakaszhatárokon bekövetkező események, mint a nyugdíjazás is hozzájárulhatnak (Warren és Garthwaite, 2014). Mivel a felszabaduló időt értékes társadalmi aktivitással töltheti a személy, így az idősebb személyek számára egyértelmúen a hospice önkéntesség szociális hozadékai a legfontosabbak (Planalp \& Trost, 2009). Erre utalhat az önkénteseknél megfigyelt magasabb altruizmus és társadalmi felelősségvállalás is (Claxton-Oldfield, Wasylkiw, Mark, \& Claxton-Oldfield, 2011). A fiatalabbak számára a hospice önkéntesség gyakran a munkatapasztalat és egy specifikus karrierút megalapozásának eszköze, valamint a társadalom előtti énbemutatásnak és státusznövelésnek az alapjait teremti meg (Claxton-Oldfield és mtsai, 2011).

Morris, Wilmot, Hill, Ockenden és Payne (2012) áttekintő vizsgálatukban az alábbi tényezőket azonosították a hospice önkéntesség fő motivációs tényezőiként: altruizmus, társadalmi felelősségvállalás, szabadidő-eltöltés, személyes növekedés, önmagunk bemutatásának, illetve jó színben feltüntetésének szándéka, a szabadság, rugalmasság. Egy koreai vizsgálatban (Kim és Kim, 2015) 158 hospice önkéntes motivációit vizsgálva a fenti té- 
nyezőkön túl kiemelik a szerzők a földrajzi szempontból közel élő ismerősök (pl. szomszédok) érdekében végzett hospice önkéntességet is, amelyet a személyek több mint $40 \%$-a említette fó motívumként, valamint a résztvevők negyede által kiemelt vallásos meggyőződésből fakadó önkéntességet. Úgy túnik tehát, hogy az önkéntesség univerzális motivációs jellegzetességein túl a kulturális jellemzőket is érdemes megvizsgálni (pl. individuális vs. kollektivista társadalmak elvárásrendszere).

Egy friss kutatásukban Nissim, Emmerson, O’Neill, Marchington, Draper és Rodin (2016) egy éven át követték 82 hospice önkéntes motivációs bázisát, az önkéntes szereppel és a szervezettel kapcsolatos elégedettséget, a haldoklással és a halállal kapcsolatos félelmeket és szorongást. Eredményeik arra utalnak, hogy az önkéntesek motivációs háttere főbb vonalaiban nem változott az idő előrehaladtával, míg az önkéntes munkával kapcsolatos elégedettségük növekedett. A haldoklással és a halállal kapcsolatos viszonylag erős kezdeti szorongás 6 hónappal a munkavégzés kezdete után (gyakran a halállal való napi szintú szembenézés és a megküzdési módok fejlődése miatt) jelentősen enyhült.

Jack, Kirton, Birakurataki és Merriman (2012) kvalitatív módszertannal (egyéni és fókuszcsoportos interjú) ugandai palliatív szolgáltatásokban dolgozó önkéntesek ( $n=43$ ) legfóbb ösztönzőjeként az önkéntességgel összefüggő büszkeségérzést és az ebből fakadó társadalmi elismerést, valamint a másokon való segítés kultúráját említik. Francia hospice önkéntesek mintáján az altruizmus ugyancsak mint vezető motívum jelenik meg Garbay, Gay és Claxton-Oldfield (2015) vizsgálatában. Elliot és Umeh (2013) által meginterjúvolt önkéntesek egyöntetúen kiemelték a társadalmi felelősségvállalás különböző komponenseit („,visszaadni valamit a társadalomnak”, „hozzájárulni valami nagyobb dologhoz"), miközben az önkéntesség kölcsönösen jutalmazó aspektusát is leírják („,minden tapasztalatból tanultunk valamit", ,"számos képességem ekkor fejlődött kiemelkedően”).

Andersson és Öhlén (2005) 10 hospice-ban dolgozó önkéntes személlyel végzett interjú elemzésével három fő motivációs tényezőt azonosított: egyfelől megismerkedni a szolgáltatással és aktívan foglalkozni a betegekkel; másfelől erőteljes igény arra, hogy a társadalom és a szúkebb közösség elismerje az önkéntes gondoskodó viselkedését; végül pedig annak vágya, hogy a hospice-szal kapcsolatos pozitív tapasztalatok elősegítsék a személyes növekedést, illetve fejlődést.

A miskolci Fényi Gyula Jezsuita Gimnáziumban 2002-ben indult Arrupeprogram keretében a középiskolás diákok hospice osztályon végezhettek önkéntes munkát. 2016-ig 60 diák végezte ezt a szolgálatot, amely egy évig tartott és körülbelül heti rendszerességgel látogatták a betegeket. Feladatuk kifejezetten a betegekkel való beszélgetés volt. A diákokkal készített inter- 
júkban motivációként a saját haláltól való félelem leküzdését, illetve a másoknak adni tudást, mások segítését emelték ki (Velkey, 2016).

Fontos látnunk, hogy az önkéntesek gyakran elutasítottnak érzik magukat, ha a hospice közösséghez tartozás nem alakul ki (nem fogadják be őket), és ha a jelentőségteljes munka végzése iránti igényük nem teljesül, vagyis ha az önkéntes munkájuk céljait nem látják világosan, vagy munkájukat hiábavalónak, netán fölöslegesnek élik meg. Ekkor az önkéntesség élettel való elégedettségre gyakorolt egyébként pozitív hatása kevésbé érvényesül (Konrath, Fuhrel-Forbis, Lou, \& Brown, 2012).

Végül érdemes arra is kitérnünk, mi állhat annak hátterében, hogy valaki nem vállal önkéntes munkát a hospice szolgáltatásban: leggyakrabban az időhiányról vagy az érdeklődés hiányáról számolnak be a személyek, valamint az észlelt nehézségek, hátrányok is fontos visszatartó eróvel bírnak (pl. anyagi vagy idóbefektetés magas volta). A hospice önkéntesség abbahagyásának okait vizsgálva leginkább a személyes körülményeket találjuk, például a munkahely változása vagy a költözés, valamint a fizetett munka terhelésének növekedése és a kiábrándulás (Claxton-Oldfield \& ClaxtonOldfield, 2008a; Thomas \& Finch, 1990). A lemorzsolódás másik lehetséges oka a kezdeti magas szintú szorongás és halálfélelem, valamint a családi és munkahelyi terhelés növekedése (Amenta, 1984; Brown, 2011a; Paradis \& Usui, 1987, 1989), azonban korábban már szó esett arról, hogy ez a szorongás általában csak az első évben okoz nehézséget.

A fenti problémák elkerülése érdekében érdemes figyelni arra, hogy a beteg és az önkéntes közötti kapcsolatot a szakemberek (pl. ápolók) és az önkéntes koordinátor is segítsék a maguk eszközeivel (pl. jelentőségteljes feladat adásával, reális célok felállításával, mentálhigiénés segítségnyújtással). Természetesen fontos szerepet tölt be az önkéntes szervezet társadalmi megítélése is az önkéntessé válásban (pl. ismertség, népszerúség), a pozitív státusz a sikeres együttmúködés lehetőségét jelezheti az önkéntesnek, egyben a szervezet iránti lojalitás legfőbb biztosítéka marad a későbbiekben is, főként, ha pozitív személyes tapasztalatokkal társul (MacNeela, 2008).

\section{A hospice önkéntesek személyisége}

A hospice önkéntesség erősen szociális természete és nagyfokú érzelmi bevonódást igénylő jellege miatt nem meglepő, hogy az önkénteseket általában magasabb empátia és érzelmi válaszkészség, gondoskodó attitüd és alacsonyabb szorongás jellemzi, mint önkéntes munkát nem végző társaikat (Lamb és mtsai, 1985). Az ide vonatkozó kutatások többsége (Briggs, 1987; Lafer, 1989; Mitchell \& Shuff, 1995; Paradis \& Usui, 1987) szerint a hospice önkéntesek legfőbb jellemzői az introspekcióra való hajlam, alázat, rugalmasság, türe- 
lem, érettség, kreativitás, alacsony impulzivitás, önbizalom, az emberek megértésének képessége. Starnes és Wymer egyik korai (2000) áttekintésében az önkéntesek leginkább a tolerancia, részvét, empátia és az érzékenység vonásaival voltak jellemezhetők. A hospice önkéntesek személyiségvizsgálataiban fóként a Myers-Briggs Típus Indikátort (MBTI; Myers, McCaulley, \& Most, 1985, az ezzel kapcsolatos kutatásokat lásd Caldwell \& Scott, 1994, valamint Mitchell \& Shuff, 1995 publikációiban) és a Big Five („Nagy Ötök”) személyiségvizsgáló eljárásokat használták. Jelen áttekintésünkben - főként a mérőeszközök megbízhatósági mutatói alapján - az utóbbira térünk ki részletesebben. A napjainkban legszélesebb körben használt és elfogadott Big Five személyiségteszt használatával Claxton-Oldfield és Banzen (2010) kanadai hospice önkéntes nőknél $(\mathrm{n}=84)$ szignifikánsan magasabb Barátságosság, Extraverzió és Nyitottság, valamint alacsonyabb Neuroticizmus értékeket talált, mint a felnőtt nőkre vonatkozó sztenderd értékek. Előbbi értékek arra utalnak, hogy az önkéntesekre nagyobb érzelmi melegség, szociabilitás, gondoskodásigény, aktivitás jellemzó, mint nem önkéntes társaikra, utóbbi (az alacsony Neuroticizmus) azt jelenti, hogy az önkéntesek érzelmi stabilitása magasabb szintú, képesek nehéz helyzetekben is nyugodtak maradni és az érzelmek magasabb fokú kontrollja, mások (gyakran erőteljes) érzelmi reakcióinak higgadt kezelése jellemzi őket, ami a racionális helyzetértelmezés révén hatékony megküzdési stratégiák alkalmazásához vezethet. Ugyanezen vizsgálatban az empátia tekintetében is magasabb értékeket találtak az önkénteseknél, főként a kognitív empátia mutatóiban mutatkozik különbség: magasabb empátiás törődés (együttérzés másokkal és törődés mások problémáival) és a szociális nézőpontváltásra való képesség (más személyek nézőpontjából tekinteni a dolgokat) jellemzi őket (lásd még Egbert \& Parrott, 2003). Ugyanakkor a segítséggel összefüggő distressz érzése ritkább az önkénteseknél, vagyis természetesebb számunkra, hogy segítenek másokon, és ez nem megterhelő számukra oly mértékben érzelmileg, mint a nem önkéntesek számára (például nem ijednek meg, ha valaki segítségre szorul a közelükben). Hasonló módszertant alkalmazva Claxton-Oldfield, ClaxtonOldfield és Paulovic (2013) brit hospice önkéntes nőket $(n=120)$ vizsgálva a brit és amerikai felnőtt nemi sztenderd értékeknél magasabb Barátságosság és Lelkiismeretesség és alacsonyabb Neuroticizmus átlagpontszámokat találtak. Összehasonlítva ezen vizsgálat eredményeit a korábban ismertetett kanadai vizsgálati minta eredményeivel (Claxton-Oldfield \& Banzen, 2010), valamint az amerikai NEO-FFI sztenderd értékekkel, egyetlen Big Five dimenzió tekintetében sem találtak szignifikáns eltérést a korábban már ismertetett eredményektől.

Ugyancsak érdekes Murrant és Strathdee (1995) vizsgálata, akik azokat a személyiségvonásokat emelték ki, melyek megléte nem szerencsés a hospice önkéntes munka végzése során. Ezek: Zárt gondolkodás, merev hiedelem- 
rendszer (a világot, és azon belül a szenvedést csak egy, sokszor igen pesszimista nézőpontból szemlélik), ami az eltérő gondolkodású betegekkel komoly összetúzéseket eredményezhet. Probléma lehet, ha valaki megoldatlan gyászfolyamata közben jelentkezik önkéntesnek - magának is szakmai segítségre lenne szüksége patológiás gyásza feldolgozásához. Ilyenkor szervezeti szinten megoldást jelenthet, ha például a saját veszteségélmény után minimum egy év elteltével jelentkezhet valaki önkéntesnek (Werner, Chard, Howkins \& Marshall, 1985). Nem szerencsés továbbá, ha valaki könnyen haragra gyúl az őt körülvevő emberek iránt (impulzív), ha folyton hibát keres másokban, „szőorszálhasogató”. Ha ragaszkodik saját véleményének, szándékának érvényesüléséhez, nem kompromisszumkész. Ha beszédkényszere van: minden üres teret és időt szavakkal akar betölteni, elszalasztja azokat a lehetőségeket, amikor az empátiás odafigyelésre és aktív hallgatásra volna lehetőség. Ha olyan témákat erőltet, amelyek a betegeknek fájdalmasak vagy ijesztók. Végül, ha túlzottan elkötelezett az önkéntes: nehezen tudja a saját határait tartani, túlvállalja magát, kényszert érez a folyamatos segítésre (lásd helper szindróma), amitól pedig hamar kimerülhet.

Az önkéntes koordinátorok számára hasznos lehet tehát személyiségtesztek alkalmazása, mivel az önkéntes munka végzése során számos olyan képesség szükségeltetik (pl. értő figyelem és titoktartás), amelyek tréningeken jól elsajátíthatók, viszont néhány személyiségjellemző (pl. részvét, másokkal való törődés) ilyen tréningeken már kevésbé fejleszthető (ClaxtonOldfield, Claxton-Oldfield \& Paulovic, 2013). Természetesen a fent ismertetett személyiségvonásokkal kapcsolatban longitudinális módszertan segítségével érdemes lenne tisztázni, hogy azok inkább az önkéntességre „hajlamosító” alapvető személyiségvonásoknak tekinthetők, vagy épp ellenkezőleg, az önkéntesség hatására válik jellemzőbbé az adott vonásstruktúra az illetőre, valamint hogy a distressz hiánya oka vagy következménye-e az önkéntes munkának (pl. hatékony megküzdés által).

\section{A hospice önkéntesség pszichés hatásai}

Field és Johnson 1993-ban publikált kutatása szerint a hospice-ban tevékenykedő önkéntes munkája során számos pozitív hatást tapasztal meg: fontosnak, értékesnek érzi magát; olyan munkát végezhet, amelyben hisz, amit előre vivőnek és konstruktívnak észlel. Mivel kimozdul otthonról, folyamatosan szembesül más emberek élethelyzetével, élettörténetével, amihez ún. szociális nézőpontváltásra van szüksége. Ez még nyitottabbá, elfogadóbbá teszi, növeli az empátiás késztetését. Új tapasztalatokat szerez, döntésképessége nő, kipróbálja magát új feladatokban. Megbecsülés, hála övezi a tevékenységét, ami pozitív hatást gyakorolhat az önértékelésére. 
Jobb önismeretre tesz szert, a saját problémáit kevésbé észleli megoldhatatlannak. Új ismeretségeket, barátságokat köt, amely a társas támogatás révén közvetlenül is pozitív hatást gyakorolt a pszichés-szomatikus állapotára. Karrier szempontjából előnyt jelenthet, hiszen a munkaadók örömmel látják, hogy elkötelezett az önfejlesztés, az önismeret bővítésének, szociális értelemben vett fejlődésének irányában. Sokan számolnak be arról, hogy egyszerúen élvezetes, önjutalmazó tevékenység számukra a hospice önkéntesség (Field \& Johnson, 1993).

Claxton-Oldfield és Claxton-Oldfield (2007) 23 palliatív ellátásban dolgozó önkéntessel készített mélyinterjúkat elemezve arra jutottak, hogy a kanadai önkéntesek több mint 50\%-a személyes érintettségböl (családtag vagy barátok halála) fakadóan jutott el az önkéntes szervezetekhez, és jelentős részük komoly változást észlelt magán az önkéntesség elkezdése óta: megtanulták átkeretezni a velük történt eseményeket, elfogadni a halál tényét, más színben látják a világot és az őket körülvevő embereket, és személyes fejlődésről számoltak be. A szerző́k azt is kiemelik, hogy az önkéntesek a mindennapi életüket annak kihívásteli aspektusaival együtt is jobban elfogadják, és jelentudatosabban élnek. Beasley és munkatársai (2015) félig strukturált interjút alkalmazó vizsgálatában az ausztrál önkéntesek is arról számoltak be, hogy tevékenységük hatására az egzisztenciális kérdések és egyben saját életük mélyebb megértése is lehetővé vált számukra, a személyes növekedés érzését és a tevékenység jutalmazó voltát megtapasztalva, miközben más emberek küzdelmeire, élethelyzetére is figyelmet tudtak fordítani. Konrath és munkatársai (2012) áttekintésükben arra jutottak, hogy a gyakori önkéntesség jelentősen csökkenti a halálozás kockázatát 4 évvel később, de ez az összefüggés csak a másokra irányuló (altruisztikus) önkéntes motivációk dominanciája esetén igazolódott. Scherwitz, Pullman, McHenry, Gao, Ostaseski (2006) 46 olyan hospice önkéntes 1 éves prospektív vizsgálatának kvalitatív tartalomelemzését végezte el, akiknek életkora 22 és 65 év közötti, és a zen buddhizmus elveit gyakorolták. Arra a következtetésre jutottak, hogy azok az önkéntesek, akik a kérdőíves vizsgálat alapján a leginkább elégedettek voltak az életükkel, legfontosabb motivációnak a másokon való segitségnyújtást nevezték meg („Hozzájárulhassak mások állapotának javulásához, ha tudok"). A legalacsonyabb élettel való elégedettségről beszámoló önkéntesek viszont számottevően több egoisztikus motivációt említettek, az önkéntes tevékenység végzésétől valamely pszichés vagy gyakorlati igényük megvalósítását remélték („Felfedezhetem valamely addig nem ismert jellemvonásomat”). Ugyancsak gyakrabban utaltak saját magukra a beszámolóikban, például kiemelték a saját türelmetlenségüket, a hospice team tagjainak védekező és ellenséges magatartását. A legtöbb önkéntes élettel való elégedettsége, valamint spirituális elkötelezettsége erősödött, ugyanakkor haláltól való félelme csökkent a vizsgálat utolsó sza- 
kaszához érve. Érdekességként elmondhatjuk, hogy utóbbi erős összefüggést mutatott a jóga rendszeres gyakorlásával, ami megerősíti, hogy a hospice önkéntesség közben átélt stressz rendszeres testmozgás által enyhíthető (lásd: Stressz fejezet). Fontos eredményként jelenik meg a szerzők összegzésében az is, hogy az önkéntesek egy évvel a tevékenység kezdete után szignifikánsan több együttérzést éltek meg és fejeztek ki a betegek irányában, ami - egyéb moderátor változók kontrollásása révén - szinte teljes mértékben a végzett tevékenységek és az egy évig tartó, önkénteseket segító felkészítő tréning hatásának köszönhető.

\section{A hospice önkéntesség kihívásai}

\subsection{Morális dilemmák}

Ahogyan már említettük, az önkéntes munkája során számos határhelyzettel szembesülhet, amelyek egy része az általa betöltött szerepek határainak tisztázatlan voltából ered: mit tehet és mit nem a betegért, illetve hol a határ bizonyos elfogadható és nem elfogadható cselekvések között. Burbeck, Candy, Low és Rees (2014) az önkéntes és a fizetett hospice dolgozók összehasonlításakor arra a következtetésre jutottak, hogy a szervezeten belül az önkéntesek elmondása szerint észlelhető egyfajta különálló „önkéntes szerep". Az önkéntesek ugyanis időnként a közvetítő szerepét töltik be a hivatásos egészségügyi dolgozók és a betegek között. A hivatásos szakemberek néhány jellemzó vonását, esetleg habitusát (pl. professzionális szemlélet) ugyanakkor gyakran fedezik fel saját magukon is az önkéntesek, mivel a hozzátartozók számára könnyebb lehet az önkéntes szerepének ilyen keretek között történő értelmezése. Az önkéntes szerepet egy rugalmas, olykor perifériás (a fizetett munkaerőhöz képest másodlagosnak érzett), erősen szociális jellegú informális szerepként írják le az önkéntesek. Sokan azt is említik, hogy ideiglenesen családi kapcsolatokat helyettesítő szerepben találják magukat a segítés alkalmával.

Claxton-Oldfield, Gibbon és Schmidt-Chamberlain (2011) vizsgálatában 79 önkéntest kértek arra, jelezzék, mit gondolnak, mit kellene tenniük a különböző, döntést igénylő interperszonális helyzetekben (pl. „személyes tárgyak kölcsönadása a betegnek vagy családtagjainak”, , „elvállalni a beteg érdekképviseletét vagy védelmét,", ",elkísérni a beteget orvosi vizsgálatra"). Az önkéntesek válaszai alapján a kutatók az alábbi kategóriákat hozták létre: „határozott határproblémák” (amiket az önkénteseknek kifejezetten el kell kerülniük, például, „pénzt elfogadni a betegtől vagy a családjától”); „lehetséges határproblémák" (amelyeknél az önkénteseknek illik kétszer meggondolni, hogy megtegyék-e, pl. „ajándékot elfogadni a betegtől vagy családtagjai- 
tól”), és "vitatható határproblémák" (amikor az önkénteseknek tudatában kell lennie, milyen következményekkel jár a cselekvés, pl. „otthoni telefonszám megadása a betegnek és családtagjainak"). Elliot és Umeh (2013) kutatásában az önkéntesek teljesen világosnak érzékelték a fizetett munkaeró és az önkéntesek szerepköreinek, valamint saját kompetenciáiknak a határát is.

\subsection{Kapcsolat a személyzet egyéb tagjaival}

Az önkéntes munkája szempontjából kihívást jelent, ha a konfliktusok folyamatosak a személyzettel, mert például nem tisztázottak a szerepek (ki miért felelős) vagy nem fogadják be az önkéntest a szervezetbe. Ennek oka az lehet, hogy néha, főleg a kis közösségekben dolgozó önkéntesek esetében, keveredik az önkéntes munkájában a formális (hivatalos keretben történő) és az informális (pl. baráti beszélgetés formáját öltő) jelleg (Berry \& Planalp, 2009; McKee, Kelley, \& Guirguis-Younger, 2007). Ezen a ponton természetesen a hospice osztály vezetójének mediációs tevékenysége, a vitás pontok megbeszélése átlendíthet a nehézségeken. Egy friss kutatásban Phillips, Andrews és Hickman (2014) 97 ausztrál önkéntest vizsgálva arra a következtetésre jutott, hogy azon önkéntesek esetében, akik alacsonyabb szerepzavarról (, mi az én feladatom és mi a többi szakemberé”) és szerepkétértelmúségről ( $\mathrm{pl}$. „mit tehetek meg és mit nem önkéntesként”) számolnak be, a kiégés szindróma kockázata is kisebb és jobban élvezik a munkájukat. Ugyanez vonatkozik a szervezetben betöltött státusz egyértelmú voltára is (Paradis, Miller \& Runnion, 1987).

Egy fontos láncszeme az önkéntes hospice-szal való elégedettségének mértékét tekintve az a tényező, hogy milyen az ápolók önkéntesek iránti attitúdje. Ezt amerikai hospice ápolók egy csoportján $(n=50)$ vizsgálva Claxton-Oldfield, Hastings és Claxton-Oldfield (2008) az alábbi következtetésekre jutottak. Az ápolók többnyire pozitív attitúddel rendelkeznek az önkéntesek iránt. Nagy részük (57\%) szerint az önkéntesek alkalmasak és jogosultak a legtöbb hospice-ban adódó feladat elvégzésére (kivéve bizonyos gondozási feladatokat, mint például etetés, fürdetés, mozgatás), és az önkéntesek legfőbb hozzáadott értékének a gyászfolyamatban való segítést és az érzelmi-spirituális támogatást tartják. Amennyiben megkérdezik tőlük, hogy a szolgáltatás minősége szempontjából milyen fontossági sorrendet állítanának fel a különböző feladatkörök között, a következő sorrend alakul ki: ápolók, családtagok, orvosok, gyógyszerészek, önkéntesek. Az ápolók 53\%-a szerint az önkénteseknek tudniuk kell a betegek egészségügyi állapotát érintő legfrissebb információkról. Akik ezzel nem értenek egyet, azok azt gondolják, hogy az önkéntesek nem rendelkeznek ezen információk értelmezéséhez szükséges élettani ismeretekkel. Az ápolók 75\%-a szerint az 
önkéntesek megkönnyítik az ápolók munkáját, mivel olyan tevékenységeket végeznek (pl. érzelmi támaszt nyújtó személyes jelenlét), amire az ápolóknak nem mindig van ideje. 56\%-uk szerint jó lenne, ha az önkéntesek jelen lennének a multidiszciplináris team üléseken, mivel gyakran olyan dolgokat is tudnak a betegről, amit a team többi tagja nem, viszont javíthatnák az ellátás minőségét. 73\%-uk nem ismeri az önkéntesek tréningjének tartalmát.

Addington-Hall és Carlsen (2005) átfogó, 2000 brit hospice szakembert érintő vizsgálatában a hospice-stáb fele és az önkéntesek egyharmada állította, hogy növelné az elégedettségét, ha hatékonyabb visszajelzéseket kapnának a teljesítményükról és többször kérhetnének segítséget a menedzsmenttól. A fizetett szakemberek és az önkéntesek többsége igen hatékonynak írták le az együttmúködésüket, amelyet viszonylag kevés feszültség terhel, ugyanakkor a hospice szolgáltatásokban történó részvétel felfüggesztését az ápolók és önkéntesek egyharmada-fele fontolgatta. A szerzők szerint ennek okaira és a lehetséges szervezeti változásokra ilyen esetekben nagy hangsúlyt kell fektetni.

Mindezen eredmények felhívják a figyelmet arra, hogy bár az önkéntesek megítélése többségében pozitív, az önkéntesek munkájáról való tudás néhol hiányosnak tekinthetô, képzésük tartalma a hospice team tagjai számára nem feltétlenül világosak. A kétirányú kommunikáció (pl. információcsere) javítása azt is eredményezné, hogy több önkéntes érezné magát a team aktív tagjának, és csökkenne az időnkénti izoláció érzése, ami végső soron az önkéntesek megtartásához is hozzájárulhatna. Hasznos lehetne továbbá egy olyan felkészító program szervezése az ápolóknak, amelyben információkat nyújtanak számukra az önkéntesek toborzási és kiválasztási eljárásáról; szerep- és felelősségköreiről; valamint arról, hogy hogyan tehetik könnyebbé az önkéntesek az ápolók munkáját, és miért lenne jó, ha az esetmegbeszélő team tagjai lehetnének az önkéntesek is (Claxton-Oldfield és mtsai, 2008).

\subsection{A stressz}

Érdemes figyelembe vennünk, hogy a haldoklás folyamata mind a hozzátartozó, mind a beteg, mind az önkéntes számára lelkileg igen megterhelő időszak. Egyes kutatók (Chentsova-Dutton és mtsai, 2000) longitudinális vizsgálatban végstádiumú betegeket otthon gondozók és ilyen tevékenységet nem végző, de azonos közösséghez tartozó, demográfiailag illesztett kontrollcsoport tagjai között komoly különbségeket találtak olyan pszichológiai jellemzókben, mint a depresszió, szorongás és düh (magasabb érték a gondozóknál), egészségmutatók (rosszabb a gondozói csoportban). Ráadá- 
sul ezek a rosszabb mutatók az ápoltak felnőtt gyermekei és házastársai körében egyaránt kimutathatóak voltak, így azt mondhatjuk, hogy nemcsak a halálozást követő gyászfolyamat, hanem az azt megelőző végstádiumú gondozás is igen megterhelő a családtagok számára, mind a pszichés, mind a fizikai állapot romlásához is vezethet és a distressz megnövekedett szintjével jár együtt, így a proaktív megküzdés fontosságát nagyon fontos kiemelnünk. Ennek egyik fontos láncszeme az önkéntesek bevonása. A hospice önkéntes feladata - mint már eddig is láthattuk - rendkívül sokszínú, valamint egy olyan ponton kapcsolódik be a beteg életébe, ahol legtöbbször a végkimenetel már nem kérdéses, és ez rendkívüli lelki terhet ró a betegre, a családtagokra, az egészségügyi személyzetre és természetesen az önkéntesre is. Folyamatosan szembesül ugyanis a romló egészségi állapottal, majd a halállal, és nem ritka az sem, hogy a másnapi munkavégzésnél már nem találja meg az előző nap ellátott beteget, és az is rossz érzés számára, ha a beteg fiatal gyermekeket hagy maga után (Claxton-Oldfield \& ClaxtonOldfield, 2008a; Dein \& Abbas, 2005). A munkából adódó stressz tehát feldolgozásra szorul, igen hasznos, ha az esetmegbeszélő szupervíziókon az önkéntes is jelen lehet, ventilálhat, feldolgozhatja a különösen megterhelő eseteket. Az extrém stresszről leggyakrabban az önkéntesség kezdeti szakaszában számolnak be (Brown, 2011a), később egyfajta „csökkent érzékenység" és a nagyfokú tapasztalat segítheti óket az érzelmi megküzdésben. Az önkéntesek narratíváiban világosan megjelenik negatív tényezőként, ha a személyzet nem segít, nem szervez olyan eseményeket, melyek az önkéntes hospice iránti elkötelezettségét növelhetnék. Végül az is problémát okoz, ha nem tudnak meg fontos információkat a betegről a beteg családjától vagy orvosától, ha későn kapják meg a lehetőséget a beteg segítésére, ha nem tudnak érdemben segíteni, vagy ha nem értesülnek új információkról (pl. a beteg állapotának változása) (Brown, 2011a; Claxton-Oldfield \& ClaxtonOldfield, 2008b). Nehézség, amikor a családtagok az önkéntes előtt veszekednek, növelve az önkéntes tehetetlenségérzését, vagy amikor nem értesülnek a temetés időpontjáról, ami az önkéntes szerint egy nagyon fontos lépés a gyászfolyamatban (Brown, 2011a). Az önkéntesek megnövekedett stressz-szintje valószínúbb akkor, amikor a gondozott elhalálozik, illetve amikor a fokozatos állapotromlás közbeni tehetetlenségérzést élik át, ám ezt a stresszt gyakran csak ideiglenesnek írják le (Dein \& Abbas, 2005). Mivel egy beteg halála a saját hozzátartozó elvesztésének érzését hívhatja elő, a halálesettól számított egy éven belül nem javasolt hospice önkéntes tevékenység elkezdése (Paradis, Miller \& Runnion, 1987).

Morris és munkatársai (2012) szerint a hivatásos személyzettól, vagy az önkéntes koordinátortól érkező nem elégséges érzelmi támogatás, a velük való nem megfelelő kommunikáció, a halállal és a haldoklással való folya- 
matos szembenézés ténye, a folyamatos tréningek hiánya, a családtagokkal való kapcsolattartás időleges nehézségei, az eszköztelenség és a személyzettől érkező leértékelő megjegyzések és rossz bánásmód tekinthetók a hospice önkéntesség legkomolyabb kihívásainak. A korábban említett koreai kutatásban az önkéntesek a legjelentősebb stresszorokként a szakmai tudás és képességek hiányát, a betegekkel való kapcsolatból eredő problémákat, valamint az időhiányt nevezték meg, de a fizikai nehézségek (pl. betegek megemelése) is szerepet játszottak az önkéntesek időnkénti elégedetlenségérzésében (Kim \& Kim, 2015). Ugyanebben a tanulmányban a szerzők negatív összefüggést találtak az érzelmi intelligencia és a hospice-ban tapasztalt stressz-szint között, amely felhívhatja a figyelmet az érzékenyító tréningek és a társas kapcsolatok hatásaira a hatékonyabb stresszkezelésben. Fontos kiemelnünk, hogy az önkéntesség szubjektív jóllétre gyakorolt pozitív hatásának érvényesüléséhez jelentős tényező az önkéntesség időtartama és intenzitása is. Azt is látnunk kell, hogy amennyiben az önkéntesség teherként vagy kötelezettségként, és nem örömforrásként jelenik meg, vagy az egyén nem tudja feldolgozni érzelmileg a közben történt eseményeket, akár a kiégés szindróma kialakulásának valószínúsége is megnőhet (Rook \& Sorkin, 2003).

\subsection{Az önkéntesek megküzdési stratégiái}

Mint láttuk, a hospice önkéntesek nagyfokú érzelmi megterheléssel és stresszel szembesülnek, amely főként a munkavégzés kezdeti szakaszában jelenthet szokatlan nehézséget a megküzdés terén. Starnes és Wymer (2000) vizsgálatában például az önkéntes tevékenység abbahagyásának fő okaiként a kiégést, a kommunikációs problémákat, az irreális elvárásokat és az önkéntes team nem megfelelő múködését jelölték meg az önkéntesek. A hospice önkéntesekre jellemző megküzdési módok Brown (2011b) kutatása alapján kidolgozott csoportosítását az 1. táblázatban részletesen ismertetjük.

Claxton-Oldfield és Claxton-Oldfield (2007) korábban említett vizsgálatának egy másik fontos aspektusa, hogy az önkéntesek mit tehetnek annak érdekében, hogy elkerüljék a kiégés szindrómát. Ennek érdekében különböző stratégiákkal élnek: izgalmas, könnyed olvasmányok, zenehallgatás, ventilálás (a problémák, nehézségek, élmények megosztása barátokkal, kedves ismerősökkel vagy munkatársakkal), szükség esetén az önkéntességgel töltött idő csökkentése, a munkától való ideiglenes eltávolodás. Az önkéntesek gyakran alkalmaznak olyan rituálékat, melyek segítségével a saját gyászreakcióikat tudatosítják és aktuális érzelmi nehézségeiket csök- 
kentik. Montross-Thomas és munkatársai (2016) vizsgálatában például a megkérdezett önkéntesek 71\%-a alkalmazott ilyen rituálékat, ezek közül a legfontosabbak: a halottól kapott emléktárgy megőrzése, gyertya gyújtása az elhunyt emlékére, kiírni magukból a fájdalmukat egy novella vagy cikk segítségével, vagy egy emléktárgyat készíteni a veszteségélmény után közvetlenül, sétálni menni. A vizsgált önkéntesek (n = 390) közül azok, akik időnként alkalmaznak ilyen rituálékat, alacsonyabb kiégés szintről és kevesebb másodlagos traumatizációs tünetról számoltak be, mint az ilyen technikákkal nem élő társaik (Montross-Thomas és mtsai, 2016), így a rituálék hatékonyan csökkentik a veszteségélmény negatív következményeit az önkéntes számára, segítve az azzal való hatékony megküzdést. Fontos megtanulniuk az önkénteseknek a személyes határaik védelmét, valamint az érzelmi távolságtartást, amikor a beteg és családja által átélt szenvedésre tudatos távolítás segítségével csökkent érzelmi választ adnak (Elliot és Umeh, 2013). Számos kutatás kiemeli a jó humorérzék és az „együtt nevetés” stresszcsökkentésben, fiziológiai mutatók javításában és proaktív megküzdésben betöltött jótékony szerepét (Adamle \& Ludwick, 2005; Berk, 2001; ClaxtonOldfield \& Bhatt, 2016; Elliot \& Umeh, 2013; Ridley, Dance \& Pare, 2014). Dein és Abbas (2005) fókuszcsoportos vizsgálatában az alábbi megküzdési stratégiákat találta a leggyakoribbnak: a kliensektől való távolságtartás, a mélyebb elköteleződés kerülése, vallásos hit, az a tudat, hogy a beteg méltóságteljesen, és nem szükségszerúen erős fájdalmakat átélve hunyt el, az a tény, hogy sok betegnek az eltávozás a szenvedés megszúnését vonja maga után, valamint a nővérekkel és orvosokkal történő tapasztalatcsere és ventilálás is sokaknak segítséget jelent. Ugyancsak védőfaktornak tekinthető a stressz ellen az énhatékonyság, az optimizmus és az észlelt társas támogatás magas szintje (Hulbert \& Morrison, 2006). Fontos, hogy az önkéntes fogalmazza meg saját maga számára is, hogy milyen szempontból jutalmazó tevékenység számára az önkéntes munka végzése, valamint az önkéntes koordinátorok számára is fontos az önkéntesek véleményének, tapasztalatainak, észrevételeinek meghallgatása, lehetőség szerinti változtatások eszközlése a program hatékonyságának javítása érdekében. A személyzettel és a betegek családjaival való jó kapcsolat csökkenti a stressz mennyiségét és intenzitását (Paradis, Miller \& Runnion, 1987). A szerepzavar csökkentésére a szabályzatok áttekintése is segítséget nyújthat. Az önkéntesek beszámolói alapján nagy segítséget nyújthatnak az esetmegbeszélő szupervíziók és a tapasztaltabb önkéntes általi mentorálás is (Warren \& Garthwaite, 2014; Farkas, 2016). A közvetlen szorongáscsökkentésre a mozgás, illetve a mélylégzés technikája kerül leggyakrabban alkalmazásra (Dein \& Abbas, 2005; Brown, 2011b). 
1. táblázat. Az áttekintésben szereplő

legfontosabb tanulmányok főbb jellemzői

\begin{tabular}{|c|c|c|c|}
\hline $\begin{array}{l}\text { Szerzók } \\
\text { (évszám) }\end{array}$ & Téma & $\begin{array}{l}\text { Kutatási módszer } \\
\text { és minta }\end{array}$ & Fóbb eredmények \\
\hline $\begin{array}{l}\text { Claxton- } \\
\text { Oldfield, } \\
\text { Hastings } \\
\text { és } \\
\text { Claxton- } \\
\text { Oldfield } \\
\text { (2008) }\end{array}$ & $\begin{array}{l}\text { Az ápolók } \\
\text { hospice } \\
\text { önkén- } \\
\text { tesekkel } \\
\text { kapcsolatos } \\
\text { attitúdjei }\end{array}$ & $\begin{array}{l}\text { Önkitöltős papír- } \\
\text { ceruza kérdóív, Likert } \\
\text { típusú skálákkal és } \\
\text { nyílt végú kérdésekkel } \\
50 \text { fő (48 nő és } 2 \text { férfi), } \\
\text { kanadai ápoló, } \\
\text { 22-62 éves kor között }\end{array}$ & $\begin{array}{l}\text { Az ápolók 53\%-a szerint } \\
\text { tájékoztatást kellene adni az } \\
\text { önkéntesek számára a betegek } \\
\text { állapotáról; } 75 \% \text {-a szerint az } \\
\text { önkéntesek megkönnyítik az ápolók } \\
\text { munkáját; } 56 \% \text {-a szerint jó lenne, } \\
\text { ha az önkéntesek jelen lennének } \\
\text { a team üléseken; } 73 \% \text {-a nem ismeri } \\
\text { az önkéntesek tréningjének tartalmát }\end{array}$ \\
\hline $\begin{array}{l}\text { Claxton- } \\
\text { Oldfield } \\
\text { és } \\
\text { Claxton- } \\
\text { Oldfield } \\
(2007)\end{array}$ & $\begin{array}{l}\text { A hospice } \\
\text { önkéntesség } \\
\text { hatása az } \\
\text { önkéntesek } \\
\text { életvitelére, } \\
\text { attitúdjeire }\end{array}$ & $\begin{array}{l}\text { Mélyinterjú, nyílt végú } \\
\text { kérdésekkel } \\
23 \text { fó (18 nő és } 5 \text { férfi) } \\
\text { kanadai } \\
\text { betegellátásban } \\
\text { dolgozó önkéntes, } \\
\text { 28-85 éves kor között }\end{array}$ & $\begin{array}{l}\text { Az önkéntesség elkezdésében } \\
\text { a saját családtag, illetve barát } \\
\text { elvesztése fontos tényezó; } \\
\text { az önkéntesség kapcsán } \\
\text { személyiség- és attitúdbeli } \\
\text { változások: az életszemlélet } \\
\text { változása, a halál elfogadása, } \\
\text { proaktív megküzdés (pl. olvasás, } \\
\text { zenehallgatás, ventilálás) }\end{array}$ \\
\hline $\begin{array}{l}\text { Elliot és } \\
\text { Umeh } \\
(2013)\end{array}$ & $\begin{array}{l}\text { Az önkén- } \\
\text { tességgel } \\
\text { kapcsolatos } \\
\text { észlelt } \\
\text { kihívások }\end{array}$ & $\begin{array}{l}\text { Strukturálatlan face to } \\
\text { face interjú } \\
9 \text { fő ( } 5 \text { nő és } 4 \text { férfi) brit } \\
\text { önkéntes, 21-82 éves } \\
\text { kor között }\end{array}$ & $\begin{array}{l}\text { Társadalmi felelósségvállalás } \\
\text { szerepe (szeretnének valamit } \\
\text { visszaadni a társadalomnak); } \\
\text { személyes nyereség az önkéntesség } \\
\text { kapcsán (pozitív érzések, } \\
\text { perspektívaváltás, kapcsolatok); } \\
\text { kommunikációs és együttmúködési } \\
\text { készség, valamint az érzelmi } \\
\text { távolságtartás szerepe; az elégtelen } \\
\text { információk a beteg állapotáról } \\
\text { stresszt keltenek }\end{array}$ \\
\hline $\begin{array}{l}\text { Claxton- } \\
\text { Oldfield, } \\
\text { Wasylkiw, } \\
\text { Mark és } \\
\text { Claxton- } \\
\text { Oldfield } \\
(2011)\end{array}$ & $\begin{array}{l}\text { Önkéntesek } \\
\text { motivációi }\end{array}$ & $\begin{array}{l}\text { Papír-ceruza } \\
\text { kérdőívek (IMHPCV } \\
\text { és Interpersonal } \\
\text { Reactivity Index) } \\
\text { 1. alminta: } 141 \text { fó } \\
\text { egyetemi hallgató } \\
\text { (107 nő és } 34 \text { férfi), } \\
\text { átlagéletkor } 19,1 \text { év } \\
\text { 2. alminta: } 141 \text { fó } \\
\text { hospice önkéntes } \\
\text { (121 nó és } 20 \text { férfi), } \\
\text { átlagéletkor: } 59 \text { év }\end{array}$ & $\begin{array}{l}\text { A hospice önkéntességgel } \\
\text { kapcsolatos motivációk } \\
\text { az alábbi } 5 \text { fó csoportba sorolhatók: } \\
\text { altruizmus, társadalmi } \\
\text { felelősségvállalás, énbemutatás, } \\
\text { szabadidő eltöltés és személyes } \\
\text { fejlődés igénye. Utóbbi kettóben a } \\
\text { hospice önkéntesek szignifikánsan } \\
\text { alacsonyabb motivációs értékeket } \\
\text { mutatnak, mint a diákok, az első } \\
\text { kettőben viszont szignifikánsan } \\
\text { magasabbat }\end{array}$ \\
\hline
\end{tabular}




\section{(1. táblázat folytatása)}

\begin{tabular}{|c|c|c|c|}
\hline $\begin{array}{l}\text { Szerzók } \\
\text { (évszám) }\end{array}$ & Téma & $\begin{array}{l}\text { Kutatási módszer } \\
\text { és minta }\end{array}$ & Fóbb eredmények \\
\hline $\begin{array}{l}\text { Garbay, } \\
\text { Gay és } \\
\text { Claxton- } \\
\text { Oldfield } \\
(2015)\end{array}$ & $\begin{array}{l}\text { Önkéntesek } \\
\text { motivációi, } \\
\text { halállal } \\
\text { kapcsolatos } \\
\text { félelmei és } \\
\text { empátiája }\end{array}$ & $\begin{array}{l}\text { Online önkitöltős } \\
\text { kérdőívek (IMHPCV, } \\
\text { Death Anxiety Scale, } \\
\text { Interpersonal } \\
\text { Reactivity Index) } \\
113 \text { fő: } 42 \text { fó palliatív } \\
\text { egyesületnél dolgozó } \\
\text { francia hospice } \\
\text { önkéntes ( } 38 \text { nő és } \\
4 \text { férfi), } 34 \text { fó jelenlegi } \\
\text { és korábbi francia } \\
\text { hospice önkéntes } \\
\text { (25 nő és } 9 \text { férfi) és } \\
37 \text { fó (23 nő és } 14 \text { férfi) } \\
\text { korábban önkéntes } \\
\text { tevékenységet nem } \\
\text { végző személy }\end{array}$ & $\begin{array}{l}\text { Jelentős a vallásos és spirituális } \\
\text { meggyőző́dés aránya a jelenlegi } \\
\text { önkénteseknél; az önkéntessé } \\
\text { válásnál erős az altruisztikus } \\
\text { (mások életében változást generálni } \\
\text { szándékozó) motiváció, } \\
\text { a társadalmi és civil aktivitásként } \\
\text { vállalt önkéntesség kevésbé } \\
\text { meghatározó, mint a kanadai } \\
\text { önkénteseknél; a halállal } \\
\text { kapcsolatos szorongásban } \\
\text { és az empátiában nincs különbség } \\
\text { a három csoport között }\end{array}$ \\
\hline $\begin{array}{l}\text { Claxton- } \\
\text { Oldfield, } \\
\text { Claxton- } \\
\text { Oldfield } \\
\text { és } \\
\text { Paulovic } \\
(2013)\end{array}$ & $\begin{array}{l}\text { Önkéntesek } \\
\text { személyiség- } \\
\text { vonásai }\end{array}$ & $\begin{array}{l}\text { NEO-FFI személyiség- } \\
\text { vizsgáló teszt, papír- } \\
\text { ceruza alapon } \\
120 \text { fő brit felnőtt női } \\
\text { önkéntes, átlagéletkor: } \\
63 \text { év }\end{array}$ & $\begin{array}{l}\text { Az USA-beli és brit felnőtt nói } \\
\text { sztenderd értékekhez viszonyítva } \\
\text { a brit hospice önkéntes nők } \\
\text { szignifikánsan alacsonyabb } \\
\text { Neuroticizmus, viszont magasabb } \\
\text { Barátságosság és Lelkiismeretesség } \\
\text { pontszámai }\end{array}$ \\
\hline $\begin{array}{l}\text { Brown } \\
\text { (2011a) }\end{array}$ & $\begin{array}{l}\text { Stressz } \\
\text { a hospice } \\
\text { önkéntes } \\
\text { munkában }\end{array}$ & $\begin{array}{l}\text { Félig strukturált } \\
\text { interjú, nyílt végú } \\
\text { kérdések a stressz és } \\
\text { megküzdés kapcsán } \\
15 \text { fő hospice önkéntes } \\
\text { (11 nő és } 4 \text { férfi), } \\
\text { átlagéletkor: } 58 \text { év }\end{array}$ & $\begin{array}{l}\text { A hospice önkéntes munka } \\
\text { összességében nem stresszes, } \\
\text { de vannak kihívást rejtő aspektusai: } \\
\text { az elsó élmények általában } \\
\text { nehezebbek, majd fokozatosan } \\
\text { „edződik hozzá” a kihíváshoz } \\
\text { az önkéntes. Ebben sokat segít, } \\
\text { ha az önkéntes hisz abban, hogy } \\
\text { végre tudja hajtani feladatát. } \\
\text { Eloofordultak fizikai tünetek } \\
\text { (fáradtság, alvási nehézségek). } \\
\text { Legjelentósebb kihívások: } \\
\text { a családtagokkal való } \\
\text { kapcsolattartás és a haldoklás } \\
\text { végigkísérése, a betegtől érkezó } \\
\text { elutasítás, a temetésre való } \\
\text { meghívás elmaradása }\end{array}$ \\
\hline
\end{tabular}


(1. táblázat folytatása)

\begin{tabular}{|c|c|c|c|}
\hline $\begin{array}{l}\text { Szerzók } \\
\text { (évszám) }\end{array}$ & Téma & $\begin{array}{l}\text { Kutatási módszer } \\
\text { és minta }\end{array}$ & Fóbb eredmények \\
\hline $\begin{array}{l}\text { Brown } \\
(2011 b)\end{array}$ & $\begin{array}{l}\text { Megküzdési } \\
\text { módok }\end{array}$ & $\begin{array}{l}\text { Félig strukturált } \\
\text { interjú, nyílt végú } \\
\text { kérdések a stressz } \\
\text { és a megküzdés } \\
\text { kapcsán } \\
15 \text { fó hospice önkéntes } \\
\text { (11 nó és } 4 \text { férfi), } \\
\text { átlagéletkor: } 58 \text { év }\end{array}$ & $\begin{array}{l}\text { A megküzdési módok } \\
\text { csoportosítása: } \\
\text { Problémafókuszú megküzdés } \\
\text { (pl. tanácskérés a team tagjaitól), } \\
\text { érzelemfókuszú megküzdés (pl. beszél- } \\
\text { getés, elmenni temetésre), jelentés- } \\
\text { adás (pl. vallásos magyarázat } \\
\text { keresése, a halált az élet részének } \\
\text { tekinti, pozitív életszemlélet) } \\
\text { és fizikai megküzdési technikák } \\
\text { (pl. séta, háziállatok gondozása, } \\
\text { mélylégzés) }\end{array}$ \\
\hline $\begin{array}{l}\text { Claxton- } \\
\text { Oldfield } \\
\text { és Bhatt } \\
(2016)\end{array}$ & $\begin{array}{l}\text { A humor } \\
\text { szerepe a } \\
\text { hospice } \\
\text { önkéntesség- } \\
\text { ben }\end{array}$ & $\begin{array}{l}\text { Önkitöltős kérdőív } \\
\text { nyílt végú } \\
\text { kérdésekkel, Likert } \\
\text { típusú skálákkal } \\
\text { és eldöntendő } \\
\text { kérdésekkel } \\
32 \text { fő hospice önkéntes } \\
\text { (27 nő és } 5 \text { férfi), } \\
\text { átlagéletkor: } 64,1 \text { év }\end{array}$ & $\begin{array}{l}\text { Az önkéntesek többsége szerint a } \\
\text { humornak helye van a hospice-ban; } \\
\text { az esetek felénél a betegek } \\
\text { kezdeményezik a humort, } \\
\text { alkalmazása függ a betegek } \\
\text { állapotától és személyiségétől; } \\
\text { a beteg megismerése mindig } \\
\text { megelőzi a humor alkalmazását; } \\
\text { az önkéntesek szerint a humor } \\
\text { csökkenti a feszültséget és a } \\
\text { stresszt, segíti a kapcsolatteremtést, } \\
\text { figyelemelterelésként múködhet, } \\
\text { a nevetés gyógyít és fájdalmat } \\
\text { csillapít, segít az önkéntes lelki } \\
\text { terheit csökkenteni }\end{array}$ \\
\hline
\end{tabular}

\section{9. Összefoglalás}

Jelen tanulmány azt a célt túzte ki, hogy az utóbbi évtizedek releváns szakirodalmának áttekintésével bemutassa a hospice önkéntesek motivációinak, észlelt nehézségeinek, stresszel való megküzdésének, személyiségvonásainak főbb jellegzetességeit. A szakirodalmi összegzés célja az volt, hogy a témához tartozó irodalom bemutatásán keresztül levonja azokat a következtetéseket, amelyek segíthetik az önkéntes koordinátorokat az önkéntesek szükségleteinek feltárásában, és a kapott eredmények szakszerú felhasználásában az önkéntes menedzsment terén, valamint a még hatékonyabb szervezésben. A hospice önkéntesség kognitív, érzelmi és viselkedéses kihívásokkal egyaránt szembesíti az önkéntest (Elliot \& Umeh, 2013). A hospice 
önkéntesség elkezdése, majd később folytatása erős kapcsolatot mutat a magas szintú altruisztikus motivációkkal (pl. társadalmi felelősségvállalás, proszociális értékek kifejezése), ugyanakkor az egoisztikus motivációk (pl. önértékelés növelése, személyes növekedés, szociális kapcsolatok, karrier) az önkéntesség elkezdésekor mutatkoznak jelentősnek, amely a hosszú távú önkéntessé válással számottevően csökken. A személyes érintettség, korábbi gyászmunka (pl. egy hozzátartozó halála vagy saját betegség miatt) gyakori motívum, miközben a hosszú távú önkéntessé válásra már az önkéntesként megélt tapasztalatok (az elfogadás, a valahová tartozás érzése, jelentőségteljes munka végzése és a hospice team tagjaival való hatékony együttmúködés) gyakorolják a legjelentősebb hatást (Farkas, 2016). Alapvető feltételnek tekinthető, hogy a saját gyászfolyamatban való elakadás (patológiás gyász) esetén az önkéntesség elkezdése annak - gyakran pszichoterápiás úton történő - megoldása után kezdődjön. Az önkéntesek személyiségvonásait vizsgálva a kontrollcsoportokhoz képest általában jellemző a magasabb Extraverzió, Barátságosság és Nyitottság, valamint alacsonyabb Neuroticizmus (Claxton-Oldfield \& Banzen, 2010), miközben a Lelkiismeretesség tekintetében csak bizonyos kutatásokban (pl. ClaxtonOldfield, Claxton-Oldfield \& Paulovic (2013) találtak magasabb pontszámot a hospice önkéntességet végzők esetében, mint az önkéntességet nem végző személyeknél. A nyitott gondolkodás, széles látókör, mély empátia és együttérzésre való képesség, tolerancia nagyban hozzájárul a sikeres önkéntessé váláshoz. Ez felveti azt a kérdést, hogy a hospice önkéntesek nagyfokú szociabilitása, érzelmi terhelhetósége, más kultúrákra és élettapasztalatokra való nyitottsága, valamint az érzelmi melegség, ami nagyban segíti a klienseikkel való munkát, miként játszik szerepet a kiégés szindróma elkerülésében. Ugyanis a hospice önkéntesség a nehéz érzelmi helyzetekkel (kliensek elvesztése, nővérektől és hozzátartozóktól érkező elutasítás) való hatékony megküzdést igényli, amelynek érdekében az önkéntesek gyakran élnek problémafókuszú megküzdéssel (a probléma elemzése, kognitív átstrukturálás), valamint érzelemfókuszú megküzdéssel (ima, kisállatok gondozása). Külön kiemelendő a humor alkalmazása, mely a problémahelyzet eltávolítását, a feszültség oldását és az átkeretezést egyaránt szolgálhatja, és alkalmazása a hospice team minden tagja számára jó szívvel ajánlható. Az önkéntesek gyakran hatékonyan alkalmaznak fizikai technikákat (pl. testedzés, jóga, mélylégzés, relaxáció) is. Mindezek következtében világosan látható, hogy az önkéntesek kezdeti, halállal kapcsolatos szorongása az önkéntesség első évének végére általában jelentősen csökken (Nissim és mtsai, 2016). Az önkéntesek felkészítése (hatékony tréningekkel, önkéntes mentorral) mellett a folyamatos érzelmi támasznyújtás (esetmegbeszélő szupervíziók, önkéntes koordinátorral történő rendszeres konzultációk) is kiemelten fontos, továbbá az önkéntesek kötetlen találkozói, valamint a különböző 
hospice intézmények rendszeres találkozói, partnerségi egyezményei és időnkénti szakmai eszmecseréi (Maschi, Marmo, \& Han, 2014) is oldhatják a munkavégzés okozta stresszt, és fokozhatják az önkéntes munkavégzés hatékonyságát. Az önkéntesek munkájának hatékonysága, valamint pszichés jólléte nagymértékben növelhető azáltal, hogy a hospice team hivatásos dolgozói időben értesítik az önkénteseket a beteget érintő egészségügyi vizsgálatok eredményeiról, és egyéb fontos információkról, valamint, ha a felmerülő problémákat nyitott, megoldásközpontú szemléletben folyamatosan sikerül hatékonyan kezelni. Mind a betegek, mind a team számára kiemelt fontosságú a megfelelő társas kapcsolati háló megléte, és szükség esetén segítség kérése a társaktól.

\section{Irodalom}

Adamle, K.N., \& Ludwick, R. (2005). Humor in hospice care: Who, where, and how much? American Journal of Hospice and Palliative Medicine, 22(4), 287-290.

Addington-Hall, J.M., \& Karlsen, S. (2005). A national survey of health professionals and volunteers working in voluntary hospices in the UK. II. Staff and volunteers' experiences of working in hospices. Palliative Medicine, 19(1), 49-57.

Amenta, M.M. (1984). Death anxiety, purpose in life and duration of service in hospice volunteers. Psychological Reports, 54(3), 979-984.

Andersson, B., \& Öhlén, J. (2005). Being a hospice volunteer. Palliative Medicine, 19(8), 602609.

Beasley, E., Brooker, J., Warren, N., Fletcher, J., Boyle, C., Ventura, A., \& Burney, S. (2015). The lived experience of volunteering in a palliative care biography service. Palliative and Supportive Care, 13(5), 1417-1425.

Berk, R.A. (2001). The active ingredients in humor: Psychophysiological benefits and risks for older adults. Educational Gerontology, 27(3-4), 323-339.

Berry, P., \& Planalp, S. (2009). Ethical issues for hospice volunteers. American Journal of Hospice and Palliative Medicine, 25(6), 458-462.

Black, B., \& Kovacs, P.J. (1999). Age-related variation in roles performed by hospice volunteers. Journal of Applied Gerontology, 18(4), 479-497.

Briggs, J.S. (1987). Volunteer Qualities: a survey of hospice volunteers. Oncology Nursing Forum, 14(1), 27-31.

Brown, M.V. (2011a). The stresses of hospice volunteer work. American Journal of Hospice and Palliative Medicine, 28(3), 188-192.

Brown, M.V. (2011b). How they cope. A qualitative study of the coping skills of hospice volunteers. American Journal of Hospice and Palliative Medicine, 28(6), 398-402.

Brown, S.L., Brown, R.M., \& Preston, S. (2011). A model of human caregiving motivation. In S. Brown, R. Brown, \& L. Penner (Eds.), Moving beyond self-interest: Perspectives from evolutionary biology, neuroscience, and the social sciences (75-88). New York: Oxford University Press

Burbeck, R., Candy, B., Low, J., \& Rees, R. (2014). Understanding the role of the volunteer in specialist palliative care: a systematic review and thematic synthesis of qualitative studies. BMC Palliative Care, 13(3), 1-12. 
Caldwell, J., \& Scott, J.P. (1994). Effective hospice volunteers: Demographic and personality characteristics. American Journal of Hospice and Palliative Medicine, 11(2), 40-45.

Chentsova-Dutton, Y., Shuchter, S., Hutchin, S., Strause, L., Burns, K., \& Zisook, S. (2000). The psychological and physical health of hospice caregivers. Annals of Clinical Psychiatry, 12(1), 19-27.

Clary, E.G., \& Snyder, M. (1991). A functional analysis of altruism and prosocial behavior: The case of volunteerism. In: Clark, M. (Ed.), Review of Personality and Social Psychology (119-148). Vol. 12. Newbury Park, CA: Sage

Clary, E.G., \& Snyder, M. (1999). The motivations to volunteer: Theoretical and practical considerations. Current Directions in Psychological Science, 8(5), 156-159.

Clary, E.G., Snyder, M., Ridge, R.D., Copeland, J., Stukas, A.A., Haugen, J., et al. (1998). Understanding and assessing the motivations of volunteers: A functional approach. Journal of Personality and Social Psychology, 74(6), 1516-1530.

Claxton-Oldfield, S., \& Banzen, Y. (2010). Personality characteristics of hospice palliative care volunteers: the "big five" and empathy. American Journal of Hospice and Palliative Medicine, 27(6), 407-412.

Claxton-Oldfield, S., \& Bhatt, A. (2016). Is there a place for humor in hospice palliative care? Volunteers Say "Yes"! American Journal of Hospice and Palliative Medicine. Doi: $10.1177 / 1049909116632214$

Claxton-Oldfield, S., \& Claxton-Oldfield, J. (2007). The impact of volunteering in hospice palliative care. American Journal of Hospice and Palliative Medicine, 24(4), 259-263.

Claxton-Oldfield, S., \& Claxton-Oldfield, J. (2008a). Keeping hospice palliative care volunteers on board: Dealing with issues of volunteer attrition, stress and retention. Indian Journal of Palliative Care, 14(1), 30-37.

Claxton-Oldfield, S., \& Claxton-Oldfield, J. (2008b). Some common problems faced by hospice palliative care volunteers. American Journal of Hospice and Palliative Medicine, 25(2), 121-126.

Claxton-Oldfield, S., Claxton-Oldfield, J., \& Paulovic, S. (2013). Personality traits of British hospice volunteers. American Journal of Hospice and Palliative Medicine, 30(7), 690-695.

Claxton-Oldfield, S., Gibbon, L., \& Schmidt-Chamberlain, K. (2011). When to say 'Yes' and when to say ' $\mathrm{No}^{\prime}$ : boundary issues for hospice palliative care volunteers. American Journal of Hospice and Palliative Care, 28(6), 429-434.

Claxton-Oldfield, S., Hastings, E., \& Claxton-Oldfield, J. (2008). Nurses' perceptions of hospice palliative care volunteers. American Journal of Hospice and Palliative Medicine, 25(3), 169-178.

Claxton-Oldfield, S., Wasylkiw, L., Mark, M., \& Claxton-Oldfield, J. (2011). The inventory of motivations for hospice palliative care volunteerism: a tool for recruitment and retention. American Journal of Hospice and Palliative Medicine, 28(1), 35-43.

Dein, S., \& Abbas, S.Q. (2005). The stresses of volunteering in a hospice: a qualitative study. Palliative Medicine, 19(1), 58-64.

Egbert, N., \& Parrott, R. (2003). Empathy and social support for the terminally ill: Implications for recruiting and retaining hospice and hospital volunteers. Communication Studies, 54(1), $18-34$.

Elliott, G., \& Umeh, K. (2013). Psychological issues in voluntary hospice care. British Journal of Nursing, 22(7), 377-383.

Farkas, K.R. (2016). A hospice önkéntesség szerepe - a Magyar Hospice-Palliatív Egyesület felmérése alapján. Kharón Thanatológiai Szemle, 20(2), 1-11.

Field, D., \& Johnson, I. (1993). Satisfaction and change: A survey of volunteers in a hospice organisation. Social science \& Medicine, 36(12), 1625-1633. 
Finkelstein, M.A. (2009). Intrinsic vs. extrinsic orientations and the volunteer process. Personality and Individual Differences, 46(5-6), 653-658.

Firth, A. (2013). A Volunteering and managing change in the health sector. Perspectives in Public Health, 133(5), 240-241.

Garbay, M., Gay, M.C., \& Claxton-Oldfield, S. (2015). Motivations, death anxiety, and empathy in hospice volunteers in France. American Journal of Hospice and Palliative Medicine, 32(5), 521-527.

Green, S.M., Martin, H.J., Roberts, H.C., \& Sayer, A.A. (2011). A systematic review of the use of volunteers to improve mealtime care of adult patients or residents in institutional settings. Journal of Clinical Nursing, 20(13-14), 1810-1823.

Guirguis-Younger, M., \& Grafanaki, S. (2008). Narrative accounts of volunteers in palliative care settings. American Journal of Hospice and Palliative Medicine, 25(1), 16-23.

Hulbert, N.J., \& Morrison, V.L. (2006). A preliminary study into stress in palliative care: Optimism, self-efficacy and social support. Psychology, Health and Medicine, 11(2), 246-254.

Jack, B.A., Kirton, J.A., Birakurataki, J., \& Merriman, A. (2012). The personal value of being a palliative care community volunteer worker in Uganda: a qualitative study. Palliative Medicine, 26(5), 753-759.

Kárpáty, Á. (2002). A gyász szociológiája. MTA PTI Etnoregionális Kutatóközpont. Munkafüzetek 91. Budapest. Letöltve: 2016. 06. 20-án: http:/ / mek.oszk.hu/02000/02010/02010. htm

Kim, Y.H., \& Kim, M. (2015). Occupational Stress and Emotional Intelligence in Hospice Volunteers. Korean Journal of Hospice and Palliative Care, 18(2), 112-119.

Konrath, S., Fuhrel-Forbis, A., Lou, A., \& Brown, S. (2012). Motives for volunteering are associated with mortality risk in older adults. Health Psychology, 31(1), 87-96.

Lafer, B. (1989). Predicting performance and persistence in hospice volunteers. Psychological Reports, 65(2), 467-472.

Lamb, D.H., Aubin, T.D.S., \& Foster, M. (1985). Characteristics of most effective and least effective hospice volunteers - A preliminary study. American Journal of Hospice and Palliative Medicine, 2(5), 42-45.

MacNeela, P. (2008). The Give and take of volunteering: Motives, benefits and personal connections among Irish Volunteers. Voluntas, 19(2), 125-139.

Maschi, T., Marmo, S., \& Han, J. (2014). Palliative and end-of-life care in prisons: a content analysis of the literature. International Journal of Prisoner Health, 10(3), 172-197.

McEwen, B.S. (1998). Protective and damaging effects of stress mediators. New England Journal of Medicine, 338(3), 171-179.

McKee, M., Kelley, M.L., \& Guirguis-Younger, M. (2007). So no one dies alone: a study of hospice volunteering with rural seniors. Journal of Palliative Care, 23(3), 163-172.

Mitchell, C.W., \& Shuff, I.M. (1995). Personality characteristics of hospice volunteers as measured by Myers-Briggs Type Indicator. Journal of Personality Assessment, 65(3), 521532.

Montross-Thomas, L.P., Scheiber, C., Meier, E.A., \& Irwin, S.A. (2016). Personally meaningful rituals: a way to increase compassion and decrease burnout among hospice staff and volunteers. Journal of Palliative Medicine, 19(10), 1043-1050.

Morris, S., Wilmot, A., Hill, M., Ockenden, N. \& Payne, S. (2012). A narrative literature review of the contribution of volunteers in end-of-life care services. Palliative Medicine, $27(5), 428-436$.

Murrant, G., \& Strathdee, S.A. (1995). Motivations for service volunteer involvement at Casey House AIDS Hospice. Hospice Journal, 10(3), 27-38.

Musick, M.A., \& Wilson, J. (2003). Volunteering and depression: the role of psychological and social resources in different age groups. Social Science and Medicine, 56(2), 259-269. 
Myers, I.B., McCaulley, M.H., \& Most, R. (1985). Manual, a guide to the development and use of the Myers-Briggs type indicator. Palo Alto, CA: Consulting Psychologists Press

Nissim, R., Emmerson, D., O’Neill, B., Marchington, K., Draper, H., \& Rodin, G. (2016). Motivations, Satisfaction, and Fears of Death and Dying in Residential Hospice Volunteers A Prospective Longitudinal Study. American Journal of Hospice and Palliative Medicine, 33(4), 335-339.

Paradis, L.F., \& Usui, W.M. (1987). Hospice volunteers: The impact of personality characteristics on retention and job performance. Hospice Journal, 3(1), 3-30.

Paradis, L.F., \& Usui, W.M. (1989). Hospice stuff and volunteers: Issues for management. Journal of Psychosocial Oncology, 7, 121-140.

Paradis, L.F., Miller, B., \& Runnion, V.M. (1987). Volunteer stress and burnout: Issues for administrators. Hospice Journal, 32, 165-183.

Phillips, J., Andrews, L., \& Hickman, L. (2013). Role ambiguity, role conflict, or burnout are these areas of concern for Australian palliative care volunteers? Pilot study results. American Journal of Hospice and Palliative Medicine, 31(7), 749-755.

Planalp, S., \& Trost, M. (2009). Motivations of hospice volunteers. American Journal of Hospice and Palliative Medicine, 26(3), 188-192.

Ridley, J., Dance, D., \& Pare, D. (2014). The acceptability of humor between palliative care patients and health care providers. Journal of Palliative Medicine, 17(4), 472-474.

Rook, K. S., \& Sorkin, D. H. (2003). Fostering social ties through a volunteer role: Implications for older-adults' psychological health. International Journal of Aging and Human Development, 57(4), 313-337.

Scherwitz, L., Pullman, M., McHenry, P., Gao, B., \& Ostaseski, F. (2006). A contemplative care approach to training and supporting hospice volunteers: A prospective study of spiritual practice, well-being, and fear of death. Explore, 2(4), 304-313.

Scott, J.P., \& Caldwell, J. (1996). Needs and program strengths: perceptions of hospice volunteers. Hospice Journal, 11(1), 19-30.

Starnes, B.J., \& Wymer Jr, W.W. (2000). Demographics, personality traits, roles, motivations, and attrition rates of hospice volunteers. Journal of Nonprofit and Public Sector Marketing, 7(2), 61-76.

Stelzer, E.M., \& Lang, F. R. (2016). Motivations of German hospice volunteers how do they compare to nonhospice volunteers and US hospice volunteers? American Journal of Hospice and Palliative Medicine, 33(2), 154-163.

Stroebe, M., Schut, H., \& Stroebe, W. (2007). Health outcomes of bereavement. The Lancet, 370(9603), 1960-1973.

Thomas, A., \& Finch, H. (1990). On Volunteering: A qualitative research study of images, motivations and experiences. Volunteer Centre UK.

Velkey, K.M. (2016). Fiatalok kapcsolata a haldoklással. Egy iskolai önkéntes program tanulságai. Kharón Thanatológiai Szemle, 20(1), 18-37.

Warren, J., \& Garthwaite, K. (2014). 'We are volunteers and that sometimes gets forgotten': exploring the motivations and needs of volunteers at a healthy living resource centre in the North East of England. Perspectives in Public Health, 135(2), 102-107.

Werner, P.T., Chard, P.S., Hawkins, C., \& Marshall, T. (1982). The selection and training of volunteers for a rural, home-based hospice program. Patient Counselling and Health Education, 3(4), 124-131.

Wuthnow, R. (1991). Acts of compassion. Princeton: Princeton University Press 


\section{Köszönetnyilvánítás}

Ezúton szeretnénk megköszönni a segítséget a Magyar Hospice Alapítványnak, a Magyar Hospice-Palliatív Egyesületnek, és minden önkéntesnek, aki áldozatos munkájával segít embertársainak emberhez méltó körülmények között eltávozni. Köszönjük a Tittel Pál Könyvtár tudományos cikkek beszerzésében, valamint Dorner Eszter nyelvi lektorálásban nyújtott segítségét. Köszönjük továbbá a lektorok és szerkesztők gondos munkáját, amivel hozzájárultak a kezdeti hibák javításához.

\section{Szerzói munkamegosztás}

A kézirat elkészültéhez minden szerző hozzájárult aktív munkájával, Hatvani Andrea a magyar nyelvú szakirodalom feldolgozásával és a szöveg strukturálásával, Mosoni Anita a hospice és a palliatív szolgáltatásokkal kapcsolatos ismeretekkel, Dorner László pedig az idegen nyelvú cikkek feldolgozásával és az egységesítéssel.

\section{Nyilatkozat érdekütközésról}

A szerzők ezúton kijelentik, hogy esetükben nem állnak fenn érdekütközések, a cikk megírásához a szerzők semmiféle anyagi hozzájárulásban nem részesültek.

\section{The Review of the Current Literature on the Psychological Aspects of Hospice Volunteering DORNER, LÁSZLÓ - FÜRNÉ MOSONI, ANITA - HATVANI, ANDREA}

Background and Aims: The aim of this study is to review and synthetize the current scientific literature from the last decades concerning the psychological aspects of volunteering with special regard to its motivational and personality background and to the activities of hospice volunteers. Methods: Based on the systematic review of scientific databases (SAGE, JSTOR, Science Direct, SpringerLink, PubMed) the most relevant and issue-related Hungarian (from Kharón Thanatológiai Szemle) and foreign articles $(\mathrm{N}=60)$ were taken into consideration based on issue-relevant key words. These were then categorized and analysed based on the main aspects of hospice volunteering (motivations, personality, perceived challenges, stress factors). Results: The vast majority of research found high altruistic motivations (e.g. social responsibility, the desire for alleviating others' pain, expressing personal values, moral responsibility) among those who apply for and later continue hospice volunteering while egoistic motivations (e.g. increase of self-confidence, self-growth, social contacts, career) are regarded as highly important determinants at the beginning phase of volunteering but not of becoming a long-term volunteer. Many studies suggest that personal grieving and caring experience and former perceived health problems also play a significant role in becoming a volunteer, while positive social experience (the 
sense of belongingness, meaningful activities and efficient communication with the hospice team) makes the greatest effect on the person to become a long-term volunteer. Examining the personality characteristics of volunteers - compared to age- and gender-related test standard points and to the points of non-volunteers - a higher degree of Agreeableness, Extraversion and Openness as well as lower Neuroticism can be detected. Naturally it is important to identify whether these characteristics are the direct consequences of volunteering or they already work as self-selection criteria. Among hospice volunteers high empathetic concern, perspective taking and a need for caring were also demonstrated without which the efficiency of coping with difficult situations (losing of patients, refusal from relatives) seems to be troubled. Conclusions: Hospice volunteering needs high frustration tolerance, continuous self-knowledge development and efficient coping strategies. Examining the volunteering activity we should take into account its effect on the psychological structures of both the volunteer him/herself and the recipient of volunteering alike.

Keywords: hospice volunteering, motivation, stress, personality 